\title{
The Police Role in Investigating the Crime of Child Murder as a Result of Infidelity Relationships
}

\section{Nurfita Anggraini Tohari ${ }^{*}$ Sri Endah Wahyuningsih**) and Arpangi ${ }^{* * *}$}

*) Student of Master of Law, Faculty of Law, Universitas Islam Sultan Agung Semarang, E-mail: nurfitaanggraini@ymail.com

${ }^{* *}$ ) Lecturer of Master of Law, Faculty of Law, Universitas Islam Sultan Agung Semarang

${ }^{* * *}$ ) Lecturer of Master of Law, Faculty of Law, Universitas Islam Sultan Agung Semarang

\begin{abstract}
.
This writing aims to identify and analyze the role of the police, criminal investigation mechanisms, obstacles and solutions to the investigation of child murder resulting from adultery. The approach method used is sociological juridical, the writing specification uses descriptive analysis, the source and type of data used are primary and secondary data. Methods of data collection by observation, field research, library research, and using qualitative data analysis methods. The theories used in conducting the analysis are role theory, justice theory, and law enforcement theory. The role of the police has been carried out by the State Police of the Republic of Indonesia as a state apparatus that has the duty to always protect, protect and serve the community in order to achieve security and order. The mechanism for the investigation of the criminal act of murdering the child resulting from an affair starts from the summons of the suspect/witness/expert to the settlement and submission of the case file to the public prosecutor. Obstacles in conducting investigations include constraints on legal substance, constraints on legal structure, and constraints on legal culture. The solution in overcoming these obstacles is coordination between senior investigators and investigators who have just attended investigative training, especially for investigators who have just been appointed as investigators.
\end{abstract}

Keywords: Police; Murder; Child.

\section{Introduction}

The state of Indonesia is a state of law. As stated in Article 1 Paragraph (3) of the 1945 Constitution of the Republic of Indonesia. The 1945 Constitution is the highest law in the hierarchy of statutory regulations in Indonesia. The prevailing law in Indonesia is a system in which each part or component is interconnected in the sense of influencing and complementing each other to achieve certain goals, namely human order and order in society. ${ }^{1}$ At the next level, law is increasingly directed as a means of progress and social welfare. ${ }^{2}$

The crime of murder is an act which, intentionally or not, kills another person's life. The difference in how to commit the crime of murder lies in the legal

\footnotetext{
1 Isna, Nadhila. (2013). Mempermudah Hidup Manusia Dengan Teknologi Modern. Jakarta: Penamadani. p.13

2 Andi Hamzah. (2001). Bunga Rampai Hukum Pidana dan Acara Pidana. Jakarta: Ghalia Indonesia. p. 14 .
} 
consequences, when the crime of murder is committed deliberately or planned in advance, the legal consequence is that the criminal sanction will be heavier than the criminal act of murder which is carried out without any heavy elements, namely planned first.

The act of a biological father who has the heart to kill his child, in this context, is his own biological child and is still an infant, which is an act that is considered cruel and inhuman. In general, the killing of minors with the status of biological children is related to the motives, methods, relationships of the victims, perpetrators, and other related parties. Therefore, this criminal act is regulated in the Criminal Code, as well as the Child Protection Act No. 35 of 2014.

In connection with the activities of Investigators whose implementation can be in the form of, for example, arrest and even detention, then the criminal procedure law through provisions which compel to remove the universally recognized principle, namely the right to freedom of a person. The criminal procedure law gives certain officials the right to detain a suspect or defendant in the framework of implementing material criminal law in order to achieve order in society. ${ }^{3}$

Based on the description of the background that has been described, the authors formulate the objectives of this writing as follows: To find out and analyze the role of the police in investigating the crime of child murder resulting from an affair, and to find out and analyze the investigation mechanism of the crime of child murder resulting from an affair.

\section{Research methods}

The approach method used is sociological juridical means a research conducted on the real situation of society or the community environment with the intent and purpose of finding facts which then leads to identification and ultimately towards solving the problem. ${ }^{4}$ Writing specifications use descriptive analysis, sources and types of data used are primary and secondary data. ${ }^{5}$ Data collection methods by interview, library research, document study, and use qualitative data analysis methods.

\section{Results and Discussion}

\subsection{The Role of the Police in Investigating the Crime of Child Murder as a Result of Infidelity}

The police is a subsystem in the criminal justice system that is sufficient to determine the success and work of the whole system in providing services to the public. This is because the police are a subsystem that is directly related to

\footnotetext{
3 Dodik Hartono and Maryanto. (2018). "Peranan dan Fungsi Praperadilan dalam Penegakan Hukum Pidana di Polda Jateng", Jurnal Daulat Hukum, Vol. 1 No. 1, p. 54-55

4 http://etheses.uin-malang.ac.id/281/7/11220001\%20Bab\%203.pdf accessed on 22 October 2020 at 22:11 WIB.

${ }^{5}$ Amiruddin. (2006). Metode Penelitian Hukum. Jakarta: PT. Raja Grafindo Persada. p. 30
} 
criminals and society, so that the duties and responsibilities of the police are greater than other subsystems. ${ }^{6}$

Police or Police are at the forefront of criminal law enforcement so it is not an exaggeration to say that the Police are said to be a living criminal law. ${ }^{7}$ The Police or Police aim to realize domestic security which includes maintaining public security and order, law and order, protection, protection and services to the community and the maintenance of public order by upholding human rights. ${ }^{8} \mathrm{As}$ one of the law enforcement officers, they have their authority based on Act No. 2 of 2002 concerning the Indonesian National Police which regulates the rights and obligations of the police. In the vision of professional law enforcement, the police are seen as a very important entry point for the criminal justice system - in this case the police as gatekeepers who manage the first step in bringing the power of criminal law to bring offenders into the Criminal Justice System. ${ }^{9}$

The authority of the National Police is the authority stipulated in Act No. 2 of 2002 concerning the Indonesian National Police. The duties and powers of the National Police are detailed in Chapter III. In carrying out its duties (Article 13 and Article 14), the National Police is given the powers described in Article 15 and Article 16 with further provisions in Article 17, Article 18 and Article 19.10

One of the provisions regulating how law enforcement officers carry out their duties is contained in the Criminal Procedure Code (KUHAP) which has the objectives of seeking and approaching material truth, namely the complete truth of a criminal case, by applying the provisions of procedural law. Honestly and accurately so that a criminal act can be revealed and the perpetrator is given the fairest decision. ${ }^{11}$

In this paper, the latest case of child murder in the Boyolali Police jurisdiction is a murder that occurred in a parent who had the heart to kill his infant child. Because the child was the result of an affair, the father of the child chose to kill the baby.

Protection of children is also a commitment of the government, namely the issuance of Perpu No.1 of 2016 concerning the second Amendment to Law No. 2 of 2002 concerning Child Protection. The Perpu regulates, among other things, penalties for weighting, additional penalties and other actions for the perpetrator. Imposition to imprisonment is in the form of an additional one-third imprisonment for a minimum of 10 years and a maximum of 20 years. In addition, the threat of life imprisonment and death penalty are also considered criminal charges.

\footnotetext{
6 Eddy Santoso and Sri Endah Wahyuningsih. (2018). "Peran Kepolisian dalam Sistem Perradilan Pidana Terpadu terhadap Penanggulangan Tindak Pidana Perjudian”, Jurnal Daulat Hukum, Vol. 1 No. 1, p. 182

7 Satjipto Raharjo. (2002). Polisi Sipil dalam Perubahan Sosial di Indonesia. Jakarta: Penerbit Buku Kompas. p. 25

8 Untung S. Rajab. (2003). Kedudukan dan Fungsi Polisi Republik Indonesia dalam Sistem Ketatanegaraan (Berdasarkan UUD 1945). Bandung: CV. Utomo. p. 12

${ }^{9}$ Eddy Santoso dan Sri Endah Wahyuningsih, Op. Cit., p. 183

10 Deny Andhika Karya Gita and Amin Purnawan, "Kewenangan Kepolisian dalam Menangani Tindak Pidana Pertambangan (Illegal Fishing) menururt Undang-Undang Nomor 4 Tahun 2009", Jurnal Daulat Hukum, Vol. 1 No.1, March 2018, p. 27

11 Andhika Widya Kurniawan and Maryanto, 2020, "Using of Letter Evidence by Defndant in Murder Crime", Law Development Journal, Vol. 2 Issue 3, p. 383-384
} 
Meanwhile, alternative penalties that are regulated are the announcement of the identity of the perpetrator, chemical castration, and the installation of electronic detection devices. ${ }^{12}$

The role of the police in reducing or preventing the occurrence of many criminal acts of murder, various attempts have been made by the Indonesian National Police or the National Police as a state apparatus that has the duty to always protect, protect and serve the community with sincerity to achieve security and order. The meaning of protectors, protectors, and public servants can be formulated as follows:

- Protectors are members of the National Police are obliged to have the ability to provide protection for the community so that they are free from fear, free from threats or dangers, and feel calm and peaceful.

- Protectors are members of the National Police must have the ability to provide guidance, directions, directions, encouragement, invitations, messages, and advice that are felt to be beneficial to the community in order to create a sense of security and security.

- Servants are members of the National Police in every step of their service must be carried out morally, ethically, politely, kindly and proportionally.

\subsection{The Mechanism of Investigating the Crime of Child Murder as the Result of an Affair}

Based on Perkap Number 6 of 2019 concerning Criminal Investigation Mechanisms to initiate a criminal investigation, an Investigation Warrant is issued, the investigator or assistant investigator takes actions lawagainst people, objects or goods that are related to the criminal act that occurred. Actions in an investigation include: ${ }^{13}$

Summons; Summons to the Suspect/Witness/Expert are carried out in writing by issuing summons based on Police Reports and Investigation Warrants and in accordance with statutory provisions.

Carry out an investigation; Investigation can only be carried out after the completion of the investigation process which is marked by the issuance of an investigation warrant by the competent official at the investigating agency, by receiving a police report or complaint or information about the occurrence of a crime and the perpetrator of the crime does not automatically issue an investigation warrant, in carrying out his duties The investigator must act based on a valid investigation order issued by the competent authority.

After the issuance of a letter to carry out an investigation, the investigating team carries out the investigation process by taking the testimonies of witnesses first when the testimonies from the witnesses have been obtained, the witness testimony is the key to clarifying a criminal act and revealing who the perpetrator

\footnotetext{
12 Sri Endah Wahyuningsih, 2014, "Perlidungan Hukum terhadap Anak sebagai Korban Tindak Pidana Kesusilaan dalam Hukum Pidana Positif Saat Ini”, Jurnal Pembaharuan Hukum, Vol. III, No. 2, p. 174

13 Interview with IPTU Ahmad Masdar Tohari as Head of Criminal Investigation Unit of the Boyolali Police, on January 18, 2021.
} 
is and discovering the identity of the perpetrator, then the most important thing is to find and gather evidence.

Process activities at the scene of the incident; Once we know that a crime has occurred, which is not reported or not reported by the Police, especially the Criminal Investigators, immediately go to the TKP to carry out the Criminal Procedure Code (Perkap 14 of 2012), from TKP the Police can find out what the modus operandi is, how to do it. the murder. In the case title activity, the aim is to find and collect evidence that is left behind and with that evidence will be a point for the Police, especially the Criminal Investigator, in uncovering the crime of murder, then finding out whether an incident is a criminal act or not, and murder has already been is clearly a criminal event, but the finding of the corpse is not necessarily a murder, therefore the investigating team collects evidence, the corpse found could have died due to illness, suicide, or a crime of murder. The success of disclosing murder cases begins at the TKP, a lot of information is obtained from the TKP processing, from the TKP processing it can be seen who the witnesses are, the modus operandi, the time it occurred and what date, took the victim's fingerprint, took the victim's photo, took the victim to hospital for post mortem, carrying items found at the crime scene related to the crime of murder, whether there is a suspect's fingerprints attached to the objects found at the crime scene, then giving a line mark on the position of the corpse. When the scene of the case (TKP) is no longer sterile for did If the crime scene is processed, it will be difficult for the Police, especially the Criminal Investigators, to find and collect evidence which will hamper the investigation process.

Foreclosure; Confiscation is carried out by the investigator/assistant investigator of objects/items related to the case handled for the purpose of investigation.

Examination of Witnesses and Suspects; Witness examination is an activity to obtain information, clarity, and identity from the suspect regarding the evidence found and the elements of the criminal act that has occurred. After the police report is received by the investigator, the investigator shall summon or examine the witness, before conducting the examination the investigator explains the purpose and purpose of the examination so that the witness can understand it. Examination A witness can provide a statement or sign a testimony in a Minutes of Investigation document as evidence at a later date or a person who provides information based on his own testimony regarding the facts he has personally seen. The investigation of the suspect is carried out to explain the occurrence of the crime in accordance with the facts. Investigation of the suspect is also to examine and ask for further information in order to make clear a criminal act that has occurred.

Performing a Visum/Autopsy; Visum is a letter made by an official and made on an oath of office based on statutory provisions, this visum is carried out by the Police, especially the Criminal Investigator to find out the cause of death of the victim, the corpse is autopsied by the Forensic Doctor to determine the cause of death whether the death was caused by blunt force or poisoning, stabbed with a knife, and strangled using a rope, so that the police can conclude about the victim's death which will later become a reference for reconstructing the criminal incident. 
Results of Visum by Doctor, the Police already have 2 pieces of evidence, namely witnesses and Visum.

Arrest; Arrestis an act by an investigator in the form of temporarily restricting the freedom of a suspect or defendant if there is sufficient evidence for the purposes of investigation or prosecution and/or trial in matters and according to methods regulated by law. An arrest can be made by an investigator or assistant investigator against a suspect or by an investigator on the order of the investigator.

Detention; Detention is the placement of a suspect or defendant in a certain place by an investigator or public prosecutor or judge by ruling, in matters and according to methods regulated in this law.

Settlement and Submission of Case Files to the Public Prosecutor; The activity of completing and submitting case files is the final activity of a criminal investigation conducted by an investigator/assistant investigator, the process which includes making a resume, compiling the contents of the case file and submitting the case file must be done carefully and thoroughly so that the case file meets the requirements, is neatly arranged and systematically. The activity of completing the case file consists of making a resume, which is the activity of the investigator to compile a summary and conclusion based on the results of the investigation of a criminal act that has occurred. Then proceed with the Submission of Case Files where the activity is an activity of sending case files along with the transfer of responsibility for the suspect and evidence to the public prosecutor.

\section{Closing}

The role of the police in reducing or preventing the occurrence of many criminal acts of murder, various attempts have been made by the Indonesian National Police or the National Police as a state apparatus that has the duty to always protect, protect and serve the community with sincerity to achieve security and order. The mechanism for investigating the crime of murder of children resulting from an affair includes: Summons to the suspect/witness/expert are carried out in writing by issuing summons based on police reports and investigation orders and in accordance with the provisions of the law Autopsy, Arrest, Detention, Settlement and Submission of Case Files to the Public Prosecutor. The police will increase outreach and guidance to citizens regarding the dangers of committing criminal acts and the sanctions that will be imposed on the perpetrators. The police further improve the facilities and infrastructures so that when a crime occurs, it can be resolved optimally because of the completeness of the facilities and infrastructure owned.

\section{References}

\section{Journal/Scientific Article:}

[1] Andhika Widya Kurniawan and Maryanto, 2020, "Using of Letter Evidence by Defndant in Murder Crime", Law Development Journal, Vol. 2 Issue 3.

[2] Deny Andhika Karya Gita and Amin Purnawan, 2018, "Kewenangan Kepolisian dalam Menangani Tindak Pidana Pertambangan (Illegal Fishing) 
menururt Undang-Undang Nomor 4 Tahun 2009", Jurnal Daulat Hukum, Vol. 1 No.1.

[3] Dodik Hartono and Maryanto, 2018, "Peranan dan Fungsi Praperadilan dalam Penegakan Hukum Pidana di Polda Jateng”, Jurnal Daulat Hukum, Vol. 1 No. 1.

[4] Eddy Santoso dan Sri Endah Wahyuningsih, 2018, "Peran Kepolisian dalam Sistem Perradilan Pidana Terpadu terhadap Penanggulangan Tindak Pidana Perjudian”, Jurnal Daulat Hukum, Vol. 1 No. 1.

[5] Sri Endah Wahyuningsih, 2014, "Perlidungan Hukum terhadap Anak sebagai Korban Tindak Pidana Kesusilaan dalam Hukum Pidana Positif Saat Ini”, Jurnal Pembaharuan Hukum, Vol. III, No. 2.

\section{Books:}

[1] Amiruddin. (2006). Metode Penelitian Hukum. Jakarta: PT. Raja Grafindo Persada

[2] Andi Hamzah. (2001). Bunga Rampai Hukum Pidana dan Acara Pidana. Jakarta: Ghalia Indonesia

[3] Isna Nadhila. (2013). Mempermudah Hidup Manusia Dengan Teknologi Modern. Jakarta: Penamadani

[4] Satjipto Raharjo. (2002). Polisi Sipil dalam Perubahan Sosial di Indonesia. Jakarta: Penerbit Buku Kompas

[5] Untung S. Rajab. (2003). Kedudukan dan Fungsi Polisi Republik Indonesia dalam Sistem Ketatanegaraan (Berdasarkan UUD 1945). Bandung: CV. Utomo

\section{Regulations:}

[1] 1945 Constitution of the Republic of Indonesia

[2] Criminal Code (KUHP)

[3] Criminal Procedure Code (KUHAP)

[4] Act No. 2 of 2002 concerning the Indonesian National Police

[5] Act No. 23 of 2002 jo. Act No. 35 of 2014 jo. Act No. 17 of 2016 concerning Child Protection

\section{Internet:}

[1] http://etheses.uin-malang.ac.id/281/7/11220001\%20Bab\%203 